\title{
Slovenski esej: kronološki uvid terminoloških rešitev
}

\author{
ANITA LAZNIK \\ Šolski center Celje, Pot na Lavo 22, SI-3000 Celje, anita.laznik@sc-celje.si
}

\begin{abstract}
Esej je posebna zvrst miselne proze, ki v literarni vedi doprinese $\mathrm{v}$ tistem delu raziskovanja literature, ki ni mogoč z izključno znanstveno razpravo. Članek prikazuje reševanje terminološke variabilnosti problematike eseja v slovenski literarni vedi, in sicer bo predstavljen kronološki pregled razprav o eseju v slovenski literarni vedi, ki so izšle v knjižnih oblikah - od Literarnega leksikona Esej do Slovenske esejistike v drugi polovici dvajsetega stoletja Mirana Štuheca.
\end{abstract}

The essay is a specific genre which is beneficial for the study of literature in those areas of research literature that cannot be dealt which solely through scientific discussion. This article presents solutions for the terminological variability pertaining to the essay in Slovenian literary studies, namely, by presenting a chronological overview of published discussions that have appeared in book form - from Esej in Literarni leksikon to Miran Štuhec's Slovenska esejistika v drugi polovici dvajsetega stoletja.

Ključne besede: esej, esejistika, kronologija, literarna veda

Key words: essay, essay writing, chronology, literary science

O Izhodišče članka je esejistika, zvrst miselne proze, ki kljub številnim literarnoteoretičnim ali pregledno kronološkim razpravam ostaja relativno odprt prostor, vsaj v pogledu, ki predstavlja izčiščenost osnovnih pojmov in terminološko enoznačnost pojava. Prikazala bom reševanje terminološke variabilnosti problematike eseja v slovenski literarni vedi, in sicer bo članek predstavil kronološki pregled razprav o eseju, ki so izšle v knjižnih oblikah - od Literarnega leksikona Esej do Slovenske esejistike v drugi polovici dvajsetega stoletja Mirana Štuheca ter zaključil pregled $\mathrm{z}$ aktualnim pogledom na esej Toma Virka.

1 Triintrideseti zvezek Literarnega leksikona z naslovom Esej (1989), ki ga je pripravil Denis Poniž, uresničuje temeljno zasnovanost literarnih leksikonov, 
in sicer pomeni znanstveno obravnavo, oprto na mednarodno dogajanje, ki razlaga razumevanje literarnega življenja na Slovenskem. Sledeč temu principu je Poniž predstavil zgodovinski razvoj eseja z avtorjema, ki sta splošno sprejeta za začetnika esejske oblike - to sta Michel de Montaigne (Essais, 1580) in Francis Bacon (Essays, 1625). Omenja literarne zvrsti in oblike, ki so pomenile predstopnjo $\mathrm{v}$ razvoju eseja, največ časa pa namenja zvrstnim, tipološkim in klasifikacijskim problemom eseja ter življenju eseja pri Slovencih. Pri tem avtor loči dokumentiranje člankov, razprav, ki so jih napisali slovenski avtorji o evropskem eseju, in besedila kot »avtorefleksijo slovenskega eseja«, ki upoštevajo vsebinsko, oblikovno in duhovnozgodovinsko oziroma civilizacijsko problematiko, ki jo prinaša esej s svojim razvojem, pojavljanjem, spreminjanjem in učinkovanjem, ter literarnoteoretične oznake eseja v slovenskih literarnih teorijah (Poniž 1989: 54). Pregled resne problemske obravnave eseja na Slovenskem po mnenju Denisa Poniža začenja Janko Kos z razpravo Esej in Slovenci, ki za začetno dobo slovenskega eseja imenuje čas slovenske moderne. ${ }^{1}$ Poniž opozarja na Antona Tomaža Linharta, ki je svojemu zgodovinskemu delu dal naslov Versuch einer Geschichte von Krain und den übrigen Ländern der südlichen Slaven Oesterreichs (Poskus zgodovine Kranjske in ostalih dežel južnih Slovanov Avstrije, 1788), kar pojasnjuje z navezavo na nemško esejistično pisanje, ki je vsebinsko in tematsko raznovrstnemu pisanju dalo naslov Versuch. V slovenski literarni tradiciji do dvajsetega stoletja nimamo razvitega eseja, imamo pa nekatere polliterarne zvrsti, za katere je značilna tudi uporaba posameznih esejističnih prvin. S tega vidika Poniž navaja pomen feljtonističnega pisanja, ki se je pojavilo v Bleiweisovih Kmetijskih in rokodelskih novicah, in spisa Matije Čopa Zgodovina slovanskih jezikov in književnosti (Geschichte der slawischen Sprache und Literatur, napisano 1831) ter Janeza Trdine Pretres slovenskih pesnikov (1850). Matijo Čopa Poniž omenja kot prvega Slovenca, ki je v svoj slog pisanja implementiral esejistične prvine, vendar jih zaradi svoje strokovne usmerjenosti ni razvil do konca (Poniž 1989: 58). Za podkrepitev pravilnosti svoje trditve se avtor sklicuje na Janka Kosa, ki je v knjigi Matija Čop (1979) analiziral Čopovo polemiko Nuovo dicscacciamento di lettere inutili, das ist Slowenischer ABC-Krieg (Novo preganjanje nekoristnih črk, to je slovenska abecedna vojna, 1833) in v kateri je kljub doslednemu označevanju besedila s polemiko odkril esejistične prvine. Čeprav Poniž navaja predvsem slovensko produkcijo, ki se je navezovala na esej, lahko iz sprotnih ocen razberemo njegovo razumevanje eseja. Pritrjuje pravilnosti določitve slogovnih in oblikovnih lastnosti eseja, kot jih predstavlja Janko Kos.

${ }^{1}$ Razpravo Esej in Slovenci je Janko Kos objavil v reviji Sodobnosti leta 1979, kasneje istega leta pa je izšla kot spremna beseda knjige Sodobni slovenski esej, v kateri so izšli izbrani eseji šestnajstih avtorjev. To so: Josip Vidmar, Vladimir Kralj, Filip Kalan, Anton Ocvirk, Edvard Kocbek, Drago Šega, Jože Javoršek, Dušan Pirjevec, Bojan Štih Taras Kermauner, Primož Kozak, Boris Paternu, Ciril Zlobec, Marjan Rožanc, Kajetan Kovič in Janko Kos. 
Naslednji v vrsti raziskovalcev eseja je Anton Ocvirk, ki je v reviji Modra ptica objavil prispevek Literarni zapiski. V njem se pisec ne zadovoljuje z naštevanjem elementov, ki jih mora vsebovati esej, marveč posebej poudarja »sintetično vsebinsko zgrajenost«, torej tisto novo in neponovljivo povezavo prvin, brez katerih ni pravega ali »čistega« eseja. Pomembna je zadnja Ocvirkova ugotovitev. ${ }^{2}$ Bolj kot fluidne in spreminjajoče se definicije eseja in tipološki poskusi je važna zavest o pogojih, v katerih se sploh lahko pojavi in razvija (Poniž 1989: 67, 68).

Avtorji, ki jih kot pomembne na poti poetološke in genološke določitve eseja na Slovenskem dokumentira Poniž, so Silvester Škerl z nenaslovljenim kratkim zapisom o eseju v reviji Slovenec; Božidar Borko z razpravo v Antologiji sodobne francoske esejistike (1929), s prevodom razprave Rajmunda Habrine Češki esej in s spisom Kaj je in kaj ni esej; Anton Ocvirk z Literarnimi zapiski IV; sodelavci treh literarnih revij: Kritika (1925-1927), Modra ptica (1929-1941), Sodobnost (1933-1941), med katerimi navaja več imen (Josip Vidmar, Milena Mohorič, Stanko Leben, Filip Kalan, Janko Lavrin, Ivo Brnčić, Pero Peter Pajk); Franc Zadravec s študijo Slovenska povojna kritika in esejistika, ki jo je razširil z naslovom Pogledi na besedno umetnost v treh številkah mariborskih Dialogov (1966); Herbert Grün s Poskusom o poskusu; Anton Slodnjak z uvodom k Izbranim esejem in razpravam Ivana Prijatelja. Poniž je do Zadravčeve študije, v kateri opozarja na povojna leta, ki zaradi močnih ideoloških in političnih pritiskov niso spodbujala razvoja eseja, kritičen in njegovo opisovanje razvoja slovenskega eseja označi za ohlapno ter tu in tam netočno (Poniž 1989: 74). Grünov Poskus o poskusu Poniž imenuje prvi povojni poskus definicije eseja. Pozitiven prispevek k definiranju eseja Poniž vidi v Grünovem ugotavljanju nekaterih notranjih, metodoloških lastnosti eseja, vendar je kritičen do njegove razvrstitve slovenskih esejistov, še posebej v izboru esejev, saj mu očita precejšnje neskladje pri naštevanju primerov z njegovimi načelnimi opredelitvami in ugotavlja upoštevanje le posameznih elementov eseja (Poniž 1989: 76). Pisanje Antona Slodnjaka pozdravlja kot enega redkih poskusov karakterizacije v esejistiki nekega slovenskega avtorja, kot pomanjkljivost pa vidi njegovo nezanimanje za opredelitev do vprašanja, kaj sploh je esej. Spis, ki konkretneje opredeljuje formo eseja, predvsem v razmejitvi z njemu sorodnimi publicističnimi zvrstmi, je Borkov spis Kaj je in kaj ni esej. Poniž ne izpostavlja posebej lastnosti eseja, kot jih opredeli Božidar Borko, vendar pozitivno vrednoti njegovo pisanje z besedami: »Borkova misel je jasna in se dotika eseja $v$ tisti celovitosti in prepletenosti posameznih esejističnih prvin, ki so pomembnejše kot pa razbor tem, s katerimi se lahko ukvarja esej« (Poniž 1989: 78). Razpravljanje o eseju v slovenski tradiciji Poniž nadaljuje z omembo Draga Šege, ki je napisal uvod v Antologijo slovenačkog eseja (Antologija slovenskega eseja, 1964), v katero je zajel dvaintrideset avtorjev, od Matije Čopa do Bogomila Faturja. Antologija prikazuje razvojno pot literarnega eseja, od

\footnotetext{
${ }^{2}$ Beseda ugotovitev se nanaša na Ocvirkovo trditev, da se esej lahko začne pojavljati pri narodu, ki ima čut za umetnost in dobro razvito prozo.
} 
začetkov romantike do prve polovice enaindvajsetega stoletja, mimo moderne, ko je tudi po njegovih ocenah esej dobil očitnejšo produkcijo. Poskus zvrstne in vsebinske opredelitve eseja Draga Šege je naslednja:

Esej kot samostojna literarna zvrst sodi - ne glede na nekatere zelo pronicljive teoretične definicije, ki mu določajo prostor med konkretnim in abstraktnim, med subjektivnim in objektivnim, med literaturo in filozofijo ali znanostjo - med tiste prozne oblike, ki jih imenujemo »odprte« prav zato, ker se izmikajo točni in dokončni formalni klasifikaciji. (Poniž 1989: 79, 80)

Odprtost strukture je prisotna v literarnem eseju, ki predstavlja določeno kontinuiteto slovenskega eseja, zaradi česar zavzema tudi pomembno mesto $\mathrm{v}$ zgodovini teorije slovenskega eseja.

V nadaljevanju Poniž v knjigi Esej omenja prevod izdaje Baconovih Esejev (Essays, 1625) leta 1972. Obsežen uvod je napisal Frane Jerman in v njem postavil razliko med Baconom in Montaignem. Jermanova trditev, da je Bacon začetnik znanstvenega eseja, je posledica razlike v pisanju obeh avtorjev (Poniž 1989: 80). V knjigi Poniž več prostora namenja razpravi Janka Kosa Esej in Slovenci, saj v njej vidi presežek v dotedanjem teoretiziranju o eseju.

Tudi Kos, gledano zgodovinsko, govori o slovenski moderni kot o začetni dobi slovenskega eseja, med najbolj znanimi slovenskimi modernisti se je pravemu eseju najbolj približal Oton Župančič. Med obema vojnama in v letih po vojni je po Kosovem prepričanju primat eseja prevzel Josip Vidmar. Poniž kljub teoretičnemu in preglednemu znanju omenjene tematike Kosu očita opustitev vsaj dveh imen, ki predstavljata pomembno mesto v razvoju slovenskega eseja. To sta Herbert Grün in njegova Pisma iz stolpa (1962) ter Jože Javoršek (psevdonim za Jožeta Brejca), ki je v slovenski esej vnašal tokove evropske literature.

Uvodno študijo $O$ istoriji i savremenosti slovenačkog eseja (O zgodovini in sodobnosti slovenskega eseja) je Denis Poniž napisal za zbirko Slovenačka književnost (Slovenska književnost, 1984), ki je izšla v tridesetih knjigah pri Matici srpski v Novem Sadu. Avtor poudarja njen informativen značaj ob obravnavi posameznih problemskih vprašanj. Kronološki pregled recepcije in razumevanja eseja pri Slovencih Poniž zaključi z esejem Aleša Debeljaka Prazen prostor za esej, izdanim v knjigi Melanholične figure (1988), in kot nekaj svežega na tem področju postavlja Debeljakovo formulacijo zgodovinske potrebe eseja. Že sprejeta razlaga eseja kot sprijem subjektivnega in objektivnega, literature in znanosti, poljubnega in dokončno določenega, ki jo sprejema tudi Debeljak, ter trditev, da »čistega« eseja po vojni skoraj nimamo, sta bistveni potezi Debeljakovega kratkega eseja, ki ga Poniž v Literarni leksikon uvrsti v duhu zavedanja »kaj je esej zvrstno in vsebinsko in kako se pojavlja na Slovenskem pri piscih najmlajše generacije« (Poniž 1989: 85).

2 Drugo obsežnejšo študijo o eseju smo Slovenci dobili leta 2003 in ima naslov Slovenska esejistika v drugi polovici dvajsetega stoletja; napisal jo je Miran Štuhec. Obsežen projekt, $v$ katerem je avtor predstavil štiriinpetdeset esejskih opusov, nastalih v letih 1950-2000, vključuje tudi Štuhečevo teoretično razmišljanje 
o izmuzljivem ontološkem bistvu eseja, čeprav v uvodu zapiše, da bo teoretskim vprašanjem o eseju in njegovi poetiki $\mathrm{v}$ monografiji namenjeno manj prostora. Vsebinsko je knjiga osredotočena na prikaz esejistike posameznih avtorjev, pomemben vidik v prvem delu pa je kronološki prikaz najpogostejših tem, ki jih je obravnavala slovenska esejistika od leta 1950 do 2000. Najpomembnejši in največji delež je zasedla književna esejistika v različnih oblikah. Med njimi avtor izpostavlja refleksije aktualnega književnega stanja, reinterpretacije besedil, ki so v slovenski zavesti pomensko ustaljena, ter eseje, ki posegajo v območje ustvarjalnih postopkov in so povezani z vprašanji fenomenologije ter ontologije literature. Pomembno tematsko področje za črpanje izhodišč slovenske esejistike Štuhec imenuje narod in slovenstvo, v okviru obeh tem pa je pogosta tudi tematika jezika, ki je pri avtorjih z narodnostno ogroženega prostora posebej občutljiva. Nazadnje je v monografiji ugotovljen precejšen porast esejistike, ki se je posvečala posameznim osebnostim z namenom poudariti osebnostne lastnosti in pomen konkretnega posameznika.

$\mathrm{Na}$ tem mestu želim izpostaviti kontinuiteto Štuhečevega raziskovanja z že omenjenimi koncepti k slovenskemu eseju in opozoriti na njegove zaključke. Štuhec dosledno upošteva rabo terminov, vezanih na širšo problematiko eseja, ki jo avtor pojmovno vzpostavi v začetnem delu. Z izrazom esej Štuhec imenuje zvrst miselne proze, samostalnik esejistika označuje korpus spisov, v katerih kljub nekaterim slogovnim, zvrstnim in jezikovnim razlikam prevladuje esejska poetika. Besedo esejiziranje uporablja Štuhec v pomenu ustvarjalnega postopka, esejističnost pa označuje sestavino notranjega sloga. Avtor se zaveda pomislekov glede izbora besedil, vključenih v monografijo, zato izpostavlja besedo esejistika, »ki jo je mogoče razumeti širše kot samostalnik esej ter dovoljuje zato vsaj nekoliko obsežnejši manevrski prostor« (Štuhec 2003: 13). Opaziti je mogoče, da teoretikovo podajanje značilnosti eseja upošteva Kosovo prispodobo zemljevida eseja v obliki koncentričnih krogov s središčno čisto esejsko obliko z opredelitvijo Ludwiga Rohnerja v knjigi Nemški esej (1966), ki jo Kos označi za najtemeljitejše delo na področju eseja, saj njegove sestavine opredelijo esej »z ostrejšo, bolj sklenjeno in zanesljivo formulacijo« (Kos 1979: 455). Štuhec opisuje poetiko eseja $\mathrm{z}$ določanjem lastnosti na treh področjih:

1. področje izhodiščne motivacije za nastanek, ki ga avtor monografije imenuje področje mentalnih sestavin oz. mentalno ozadje eseja;

2. področje oblikovnih in slogovnih značilnosti in

3. področje jezikovnih določnic.

Po pregledu vseh imenovanih področij Štuhec opredeli poetiko esejev z naslednjo formulacijo: »Esej je sinteza posebnega in avtentičnega stanja duha ter slogovno uravnoteženega ustvarjalnega postopka, v katerem se hkrati odkrivata objekt in subjekt.« Omenjeno ustvarja »specifičen esejistični diskurz - v posebno sporočilo in enkratno izkušnjo, katerih središče ni zaključena sinteza, ampak ideja« (Štuhec 2003: 20).

Miran Štuhec je leta 2005 s spremno besedo opremil antologijo slovenske esejistike po drugi svetovni vojni z naslovom Aristokracija jezika in duha, $\mathrm{v}$ 
kateri je povzel glavne teoretične poudarke o eseju iz monografije Slovenska esejistika $v$ drugi polovici dvajsetega stoletja.

3 Slovenska literarna veda se je $\mathrm{v}$ teoretiziranju o eseju naslanjala predvsem na nemške teoretike (Gerharda Haasa, Ludwiga Rohnerja, Georga Lukacsa, Maxa Benseja, Hansa Wolffheima, Klausa G. Justa). To je posledica slovenske zgodovinske bližine $\mathrm{z}$ nemškim jezikom, tradicije slovenske literarne teorije in dejstva, da so se tudi sicer slovenski ustvarjalci bolj odpirali proti zahodu Evrope kot pa na vzhod ali jug. Kljub temu ni prezrla angleških teorij o eseju, kot je na primer študija o angleškem eseju Elements of the Essay (Elementi eseja, 1969) Roberta Scholesa in Carla Klausa. Leta 1997 je pri Fitzroy Dearborn Publishers Tracy Chevalier uredila enciklopedijo eseja $\mathrm{z}$ naslovom Encyclopedia of the Essay (Enciklopedija eseja, 1997), ki prinaša biografije esejistov in osnovne podatke posameznih esejev (leto prve izdaje, informacija o objavi eseja v zbirki ali antologiji) z vsega sveta. Enciklopedija je zastavljena globalno in je osredotočena na zgodovinski pregled produkcije eseja v evropsko-ameriški svet od Montaigna do sodobnosti. V nadaljevanju članka povzemam uvod enciklopedije $\mathrm{z}$ naslovom Encyclopedia of the Essay (Enciklopedija eseja), ki ga je napisal Graham Good. Enciklopedijo bralcem in bralkam predstavlja kot mesto, ki kljub različnim mnenjem podaja bistvene lastnosti eseja in uporabnike ter uporabnice hkrati usmerja v nadaljnje branje, ni pa njen namen izčiščevanje terminoloških dilem v esejistiki ali katalogizacija vseh avtorjev, ki so kdaj napisali esej. Puščanje odprtih teoretičnih vprašanj je razvidno tudi iz nedosledne rabe izrazov v uvodu. Avtor v spisu uporablja izraze, ki bi jih lahko prevedli na naslednji način: literarna oblika (literary form), esejistično pisanje (essayistic writing), esejistika $^{3}$ (essayistic literature), z vsemi naštetimi pa meri na esej kot obliko. Takšno variabilnost slovenska literarna teorija odpravlja. Vprašljivi sta predvsem besedni zvezi »essayistic writing « in »essayistic literature«. Za primer navajamo Janka Kosa, ki je v razpravi Esej in Slovenci (1979) na Slovenskem opozarjal na pomen razlike med esejem kot formo, esejističnim načinom pisanja ali celo esejističnim načinom mišljenja, in Mirana Štuheca, ki v Slovenski esejistiki v drugi polovici dvajsetega stoletja (2003) esejističnost upošteva kot sestavino notranjega sloga. ${ }^{4}$ Komentar je potreben tudi za pridevniško označevanje z izrazom literaren. Good esej označi za literarno obliko, vendar v podrobnejšem pregledu te oblike spoznava vsebinsko in slogovno drugačnost od drugih literarnih oblik, a z uporabljenim izrazoslovjem esej še vedno ohranja v prostoru literature s poudarjeno estetsko funkcijo. Avtor poudarja poseben status eseja,

${ }^{3}$ Opozarjam, da je izraz esejistika $v$ tem primeru dvoumen prevod. Goodovo sintagmo essayistic literature lahko razumemo na dva načina: (1) besedna zveza označuje korpus esejev posameznega esejista; (2) izraz označuje literarna in neliterarna besedila, $v$ katerih lahko kot prvino notranjega sloga zaznamo esejističnost.

${ }^{4}$ Ostale slogovne lastnosti za določanje tipologije esejistike Štuhec našteva pojme esejističnost, interpretativnost, razpravljalnost, polemičnost, kritičnost in študitivnost. 
ki je v ambivalentnem odnosu $\mathrm{z}$ institucionalnimi diskurzi, a ga raziskovalci obravnavajo kot vmesno kategorijo med znanostjo in umetnostjo.

$\mathrm{Z}$ besedo "generally«, ki bralca ali bralke ne zavezuje k enotnemu razumevanju oziroma vnaprej predpisanemu dojemanju eseja, Graham Good dopušča naslednje možnosti za opredelitev forme. Ugotavlja, da se izraz esej uporablja za neumetnostna besedila dolžine od ene do petdeset strani, čeprav se v nekaterih primerih mednje uvrščajo tudi daljša dela (dolžina knjige). Termin je uporabljen za označevanje določene obravnave teme, ta pa je označen kot začasen in splošen bolj kot sistematičen in končen. Nasprotje eseja je akademski članek, ki je prispevek priznani znanstveni disciplini ali skupinski raziskavi, v kateri se predhodne raziskave upoštevajo v obliki citatov in opomb. Esej je v svoji naravi bolj oseben kot sodelovalen in mu običajno primanjkuje tovrstnega znanstvenega aparata. Esejistova avtoriteta ne temelji na uradnih znanjih ali akademski ekspertizi, ampak na njegovi osebnosti, kar se izraža v slogu pisanja. Njegova prepričljivost temelji bolj na značilnosti sloga, kot na uporabi sprejetega strokovnega in tehničnega besedišča. Za esej je tipično, da se namenoma izogiba žargonu in nagovarja »splošnega bralca« v prijaznem, neformalnem tonu. Prav tako se pri posamezni temi izogiba uporabi predhodno postavljene metodologije. Raje gre od posameznega proti splošnemu in tudi takrat ne daje zaključkov, ki bi jih lahko uporabili v drugih primerih. Njegovo zanimanje je osebno in določeno, bolj kot profesionalno in sistematično.

Ohlapno definicijo lahko beremo kot stanje razumevanja problematike eseja v zavesti večinoma laične javnosti. ${ }^{5}$ Verjetnejša razlaga relativne priprtosti definicije je določenost z izborom avtorjev in besedil, vključenih v enciklopedijo. Prisotna je avtorjeva motivacija opravičevanja nekaterih spornih, morda mejnih besedil, upoštevanih v enciklopedičnem pregledu. Slovenci popolnega enciklopedičnega pregleda slovenske esejistike še nimamo, imamo pa, kot sem že zapisala, obsežno monografijo Mirana Štuheca Slovenska esejistika v drugi polovici dvajsetega stoletja, ki predstavlja kontinuiteto v raziskovanju slovenske esejistike in izčrpno že zbrano gradivo opaznejših slovenskih esejistov, ter antologijo slovenske esejistike Aristokracija jezika in duha.

4 Globalizacija na vseh nivojih človeškega življenja, neizmerno hiter razvoj tehnologije informacijskih sistemov, posledično možnost pojava hibridnosti že uveljavljenih struktur, teorij, metodologij ter mobilnosti vsega so le nekateri

${ }^{5}$ Zakaj sem označila Goodovo definicijo za ohlapno? Razlog je dvojen. Prvega sem že omenila, in sicer ga vidim v plahi maniri uporabe izraza generally, ki ga prevajam kot splošno/običajno. Kot drugi razlog citiram poved, ki ji pomensko kontekstualno lahko za sopomenko označim besedo generally v pomenu splošno/običajno. Poved govori o netogi, nestalni rabi izraza esej in neposredno uvaja zgoraj omenjeno Goodovo definicijo eseja. »Despite the huge variety of its forms, there are certain features which recur often enough to give the word »essay« a specific though not rigid meaning.« (Chevalier 1997: 27) Čeprav esej najdemo v številnih različnih oblikah, se nekatere značilnosti pojavljajo dovolj pogosto, da dajo terminu esej specifičen, vendar ne tog pomen. 
razlogi, ki v 20. stoletju še posebej v humanistiki, družboslovnih vedah in navsezadnje literarni vedi spodbujajo raziskovalce v razmislek o že sprejetih oz. kanoniziranih spoznanjih. Ne gre toliko za ugotavljanje pravilnosti ali nepravilnosti tez, temveč za zmožnost ponovnega revidiranja posameznih elementov, ki lahko strukturo predstavi na alternativen način, jo postavi $\mathrm{v}$ drugačno kontekstualno polje in s tem poskrbi za dodano vrednost $\mathrm{v}$ znanosti. Tovrstni premiki v uporabi metodoloških postopkov, pluralizem teoretičnih in idejnih temeljev, povezanih $\mathrm{z}$ mnogoterostjo vrednostnih perspektiv, se dogajajo v literarni vedi 20. stoletja. To situacijo kot pomembno prepoznavno lastnost humanističnih in družboslovnih ved opredeljujejo številne znanstvene razprave sodobnih teoretikov, med slovenskimi veliko pozornosti vprašanjem, ki nastajajo kot posledica omenjenega stanja, namenjata Marko Juvan in Tomo Virk. V kontekstu ekonomsko-kulturne globalizacije in postmodernega stanja se je, kot ugotavlja Marko Juvan, v zadnjih dveh desetletjih (po letu 1990) v primerjalni književnosti ponovno pojavila zamisel o vzpostavitvi svetovne književnosti, ki združuje posamične nacionalne književnosti, ki bodo eksemplarično predstavljale pestrost, podobnost ali različnost kulturnih konceptov, ki so osnova refleksijam na ravni posameznika, sistema in nazadnje družbe v celoti. Interakcijski moment nacionalnih literatur znotraj svetovne književnosti nujno ohranja in obnavlja strpnost $\mathrm{z}$ razumevanjem drugačnosti ter kot pomembno vrednoto izpostavlja miroljubno sožitje na različnih nivojih. Hkrati se pojavljajo spremembe znotraj znanstvenega aparata literarne vede same. Predmet raziskovanja postanejo že sprejete norme, uveljavljena spoznanja in pristopi, ki jih je literarna veda s svojimi disciplinami uporabljala več stoletij kot edine pravilne, hkrati pa je $\mathrm{v}$ do tedaj nedotakljivi prostor spustila različne študije, obrnjene $\mathrm{v}$ zunanjo resničnost - predvsem upoštevanje dejstva, da literatura posega $\mathrm{v}$ sfere zgodovinskega, psihološkega in sociološkega polja. To dejstvo kot pomembno prepoznavno lastnost humanističnih, družboslovnih ved opredeljujejo številne znanstvene razprave sodobnih teoretikov. Med slovenskimi veliko pozornosti s tem povezanim dilemam namenjata Marko Juvan in Tomo Virk.

Juvanovo aktualno razmišljanje o eseju sega na področje transverzalnih diskurzov, katerih se dotika esejiziranje v svojem bistvu. Pregled zapisov o značilnostih eseja, predvsem tistih najbolj znanih in citiranih avtorjev, kot so Georg Lukács, Theodor W. Adorno, Immanuel Kant in Michel de Montaigne, ter njihovo soočanje z novodobnimi in aktualnimi ugotovitvami o literaturi na splošno, npr. avtorjev, kot sta Derek Attridge in Timothy Clark, pokaže, da se esej postavlja $\mathrm{v}$ razmerje med dva transverzalna diskurza - to sta literatura in tiskani mediji. V obravnavi razlik v vednosti in načinu podajanja obeh Juvan imenuje kljub na videz nepremostljivi razliki njun povezovalni element. Imenuje ga sensus communis, ki ima $\mathrm{v}$ recepcijski teoriji različne pomene, pristope in interpretacije modalnosti singularnosti. Kljub sedaj splošno sprejetemu mnenju, da je esej pogojen s prostorom individualne, osebne izkušnje, ki se disciplinarno in teoretično ne želi omejevati in ki je kritičen do avtoritet, kritičnost pa se vzpostavi kot posledica osebne bivanjske izkušnje, Juvan opozarja, da se esej močno navezuje prav na sensus communis. Kot potrditev tega navaja 3 razloge: 
1. Zgodovinsko gledano je esej v preteklosti nastajal prav z medbesedilnostjo, ko se je avtorjeva misel povezovala s splošno sprejetimi resnicami, vzete iz družbenih spoznanj in zakladnice tradicionalnih znanj.

2. Sensus communis je integriran v vsebinsko osnovo esejev, ki je koncipirana $\mathrm{v}$ neliterarnih oblikah, posledično pa esejist sensus communis estetsko predela in uporabljene pojme $\mathrm{z}$ interakcij ter primerjavo postavlja $\mathrm{v}$ nov kontekst. Šele tako jim določa pomen $v$ razmerju znotraj eseja.

3. Kot tretje se sensus communis v esejih izkazuje v obliki stereotipa kot splošno sprejetega predsodka.

$\mathrm{Z}$ določanjem singularnosti eseja, ki predstavlja dvoje - elemente, ki delajo esej prepoznavne, drugačne in neponovljive, ter singularnost esejista, Tomo Virk vprašanju eseja pripisuje pomembno vlogo, saj nanj veže vprašanje glede statusa literarne vede. Odgovor na to vprašanje avtor oblikuje v odvisnosti od možnih razlag literarnosti oz. kako razlagamo literaturo. Dejstvo je, da je literatura živ organizem, ki s svojo specifiko posega na različna področja, odvisna je od številnih dejavnikov in je ne moremo izolirati od zunanjih vplivov. Tomo Virk razmišlja, da tudi ko definiramo literarnost, to počnemo $\mathrm{z}$ določene pozicije, ki ne zajema celotnega konteksta. Zato v članku Esej in narava literarnovednega diskurza zapiše:

V skladu z zakonom singularnega, prikazanem ne le v prej navedenih ugotovitvah, temveč tudi v definicijah mnogih drugih teoretikov in filozofov, je mogoče singularnost literature opisovati le v diskurzu, ki ne posplošuje, ne kategorizira, si ne prizadeva za eksaktne definicije, temveč skuša evocirati zgolj bližino, slutnjo - ki se ji moramo, kot pravi Derrida, predati -, da obstaja nekaj, česar se lahko edino dotaknemo, a tega nikoli ne moremo zajeti. Skratka: približati se ji je mogoče le z esejističnim diskurzom. (Virk 2010: 241)

Virkova in Juvanova znanstvena dognanja o eseju so kompleksna, aktualna in odprta v smislu, da dopuščata polifonost $\mathrm{v}$ razumevanju te razširjene zvrsti miselne proze, ki skozi čas dokazuje svojo fleksibilnost $\mathrm{v}$ vsebini in snovnih izhodiščih. Njuna značilnost in posebnost je naslanjanje razlage na filozofska stališča oz. na avtorje, ki so pomembno sooblikovali tako starejšo kot novejšo filozofsko misel.

Pregled predstavitev teoretičnih ugotovitev pokaže, da je bilo zanimanje za esejistiko v slovenski literarni vedi ves čas od konca 70. let 20. stoletja prisotno, intenzivnost esejističnega pisanja pa se je z leti le še povečevala. Če pristanemo na vseobsegajočo globalizacijo na vseh ravneh družbe, potem je premislek o literarnovednih spoznanjih ne samo mogoč, ampak nujen. Literarna veda je v svoji širini kompleksen pojav, ki ne miruje, se spreminja in prav esejistika s svojo odprtostjo ter fleksibilnostjo pomembno sooblikuje literarnovedni diskurz. 


\section{LITERATURA}

Theodor W. ADORNO, 1999: Beležke o literaturi. Ljubljana: Cankarjeva založba.

Max BENSE, 1974: Esej in njegova proza. Dialogi X/9, 623-630.

Matej BOGATAJ, 1991: Vrh sodobne esejistike: Marjan Rožanc: Brevir. Delo, št. 49, 13.

Wolfgand BRAUNGART, 2006: Essayismus um 1900. Heidelberg: Winter, cop.

Kenneth BURKE, 1941: The philosophy of literary form: studies in symbolic action. Louisiana: State University Press.

Tracy CHEVALIER (ur.), 1997: Encyclopedia of The Essay. London: Fitzroy Dearborn Publishers, cop.

Darko DOLINAR (ur.), 2008: Primerjalna književnost v 20. stoletju in Anton Ocvirk. Ljubljana: Založba ZRC SAZU.

Graham GOOD, 1988: The observing self: Redescovering the essay. London, New York: Routledge.

Marko JUVAN, 2006: Literarna veda v rekonstrukciji. Ljubljana: Literarno-umetniško društvo Literatura.

- - (ur.), 2012: Svetovne književnosti in obrobja. Ljubljana: Založba ZRC SAZU.

Božidar KANTE, 1999: Sodobna literarna veda in filozofija na Slovenskem: primer poststrukturalizma. SSJLK, št. 35, 137-145.

Janko KOS (ur.), 1979: Sodobni slovenski esej. Ljubljana: MK.

- -, 1988: Uvod v metodologijo literarne vede. Primerjalna književnost 11/1, 1-18.

- -, 1995: Na poti v postmoderno. Ljubljana: Literatura.

- -, 1995: Postmodernizem. Ljubljana: DZS.

- -, 2007: Slovenci in Evropa. Ljubljana: Študentska založba.

Matevž KOS (ur.), 2000: The Slovenian Essay of the Nineties. Ljubljana: Slovene Writer's Association.

Darja PAVLIČ, 2010: Esej in singularnost: uvod. Primerjalna književnost 33/1, 63-64.

Manfred PFISTER, 2005: O eseju kot o eni izmed uprizoritvenih umetnosti. Primerjalna književnost 28/1, 43-50.

Denis PONIŽ, 1989: Literarni leksikon 33. Ljubljana: DZS.

Miran ŠTUHEC, 2000: Naratologija: med teorijo in prakso. Ljubljana: Študentska založba.

- -, 2003: Slovenska esejistika v drugi polovici dvajsetega stoletja. Ljubljana: Slovenska matica.

- -, 2005: Aristokracija duha in jezika: antologija slovenske esejistike po drugi svetovni vojni. Ljubljana: Študentska založba.

- -, 2013: Književne teme. Maribor: Založba Pivec. 
Andrina TONKLI KOMEL, 1995: Subjektivno kot kriterij znanstvene ustvarjalnosti. Nova revija XIV/162, 131-135.

Tomo VIRK, 1991: Postmoderna in »mlada slovenska proza«. Maribor: Založba Obzorja.

- -, 1994: Bela dama v labirintu. Ljubljana: Literatura.

- -, 1995: Ujetniki bolečine. Ljubljana: Mihelač.

- -, 1997: Tekst in kontekst. Ljubljana: Literatura.

- -, 1998: Premisleki o sodobni slovenski prozi. Ljubljana: Zavod Republike Slovenije za šport.

- -, 2000: Strah pred naivnostjo. Ljubljana: Literatura.

--, 2003: Moderne metode literarne vede in njihove filozofsko teoretske osnove. Ljubljana: Filozofska fakulteta, Oddelek za primerjalno književnost in literarno teorijo.

- -, 2007: Primerjalna književnost na prelomu tisočletja. Ljubljana: Založba ZRC SAZU.

- -, 2010: Esej in narava literarnovednega diskurza. Primerjalna književnost 33/1, 233-243.

Franc ZADRAVEC, 1962: Slovenska literarna kritika in esejistika. Jezik in slovstvo $\mathrm{VIII} / 1-2$.

- -, 1966: Pogledi na besedno umetnost (1945-1965). Dialogi 1/9, 10-11.

- -, 1999: Slovenska književnost II. Ljubljana: DZS.

Alojzija ZUPAN SOSIČ, 2010: Literarnost, ponovno. Primerjalna književnost 33/3, 199-219.

\section{THE SLOVENIAN ESSAY: A CHRONOLOGICAL OVERVIEW OF TERMINOLOGICAL SOLUTIONS}

The starting point of this article is the essay, a genre of thinking in prose that, in spite of the many theoretical or chronological discussions, remains relatively unexplored, at least in the view which is represented in the culling of the basic concepts and terminological unambiguity of the phenomenon. The article presents solutions for the terminological variability pertaining to the essay in Slovenian literary studies, namely, by presenting a chronological overview of published discussions that have appeared in book form from Esej in Literarni leksikon to Miran Štuhec's Slovenska esejistika v drugi polovici dvajsetega stoletja, and concluding with an overview of Tomo Virk's current-day view of the essay.

Denis Poniž's thirty-third volume of the Literary Lexicon, entitled Esej (1989), is the fundamental basis of literary lexicons; it is a scholarly discussion drawing on international developments that explain the understanding of literary life in Slovenian. Following this principle, Poniž outlines the historical development of the essay by two authors that are generally considered to be the fathers of the essay form: Michel de Montaigne (Essais, 1580) and Francis Bacon (Essays, 1625). Poniž mentions literary genres and forms that functioned as precursors in the development of the essay, and he devotes most of 
his space to the essay's genre, typological and classification difficulties, as well as to the life of the essay among Slovenians. The author distinguishes documenting articles and discussions written by Slovenian authors about the European essay and texts ("the self-reflection of the Slovenian essay") which take into account the content, form and intellectual history or cultural issues brought about by the essay, with its development, appearance, alterations and effects, as well as theoretical characteristics of the essay in Slovenian literary. In Poniž's view, an overview of serious discussion of the essay in Slovenia begins with Janko Kos's Esej in Slovenci. Kos cites Slovenian modernism as being the first phase of the Slovenian essay.

This article presents the authors and important milestones in the development of the Slovenian essay up to the end of the $20^{\text {th }}$ century. General social circumstances at all levels of human life, also in literary studies, and in the humanities, motivate researchers to question knowledge in their field. In this context, consideration of literary knowledge is not only possible, but necessary. Literary studies are a broad and complex phenomenon that is not static; it changes, and the essay, with its openness and flexibility, is a crucial component in forming the discourse of literary studies. 